\title{
The Impact of Environmental Performance on Firm Value: Evidence from Indonesia
}

\author{
Bahtiar Effendi
}

\author{
${ }^{1}$ Matana University of Banten \\ *Corresponding author. Email: bahtiar.effendi90@gmail.com
}

\begin{abstract}
This study aims to analyze the variables of environmental performance on firm value in Indonesia. The environmental performance variable consists of four dimensions adopted from the Global Reporting Initiative (GRI 4.0), namely input material, non-product output, compliance aspects, and transportation aspects. The population of this research is all manufacturing companies located in Banten Province from 2016 to 2018, as many as 1,695 companies. The sample of this study consisted of five companies selected using the purposive sampling method. This study uses primary data obtained from answers to questions through a questionnaire given to 71 respondents and secondary data from the company's financial statements. Data analysis using quantitative methods descriptive approach. By using multiple linear regression analysis the results are obtained: (i) environmental performance through input material dimensions has a significant negative effect on firm value, (ii) environmental performance through non-product output dimensions has a significant positive effect on firm value, (iii) environmental performance through dimensions of compliance aspects has a positive effect but are not significant to firm value, (iv) environmental performance through the transportation aspect has a negative effect but are not significant to firm value, (v) environmental performance through input material, nonproduct output, compliance aspects, and transportation aspects simultaneously effect on firm value.
\end{abstract}

Keywords: environmental performance, firm value, Banten province

\section{INTRODUCTION}

Banten is a province with several industrial estates that have become pilots in the development of integrated industrial estates with the availability of infrastructure in Java. Saleh Husin (Minister of Industry) said that this had a positive impact in increasing production and logistics efficiency, thereby increasing the competitiveness of domestic manufactured products in the export market. The increase in investment in the Banten industrial area is quite large, because there is Soekarno-Hatta International Airport, Merak Port, the Jakarta-Merak Highway, the Jakarta-Rangkasbitung-Merak Railway Network, and most recently the Bojonegara Port and road access to three areas industry in Banten is being upgraded to support the investment enhancement program established by the central government. The three industrial areas are the Modern Cikande Industrial Estate in Serang Regency with an area of 1,800 hectares, the Wilmar Bojonegara Industrial Estate in Serang Regency with an area of 800 hectares, and the Krakatau Industrial Estate Cilegon (KIEC) in Cilegon City covering an area of 570 hectares. Based on records, the Ministry of Industry recorded 20 industrial estates spread across Banten, including Tangerang City, Tangerang Regency, Serang Regency and Cilegon City [1]. However, there is a phenomenon of imbalance between industrial estate development and environmental sustainability in Banten. Several industries that do not have raw water treatment plants, wastewater treatment plants, drainage channels, street lighting installations, and road networks. Bad environmental management will certainly cause negative impacts related to environmental damage [2].

Environmental damage in Banten continues to increase until now, especially damage to agricultural land, destruction of mountains, environmental pollution, destruction of food sources to climate change. This is evident among others in the case of PT. Sentra Usahatama Jaya (SUJ) and the reclamation of Pulorida 
Beach in Cilegon, pollution of the Ciujung river, mining of sand in the Lebak area, and the potential threat of sea sand mining on the North Coast of Banten [3]. Also, there is a phenomenon as many as 418 industries in Tangerang Regency, Banten during the 2014 to 2018 period were sanctioned by the Environment and Sanitation Service regarding waste pollution. The waste pollution carried out by the industry is like not having a liquid waste permit, chimneys that have an environmental impact and are not treated so that they do not have a TPS [4]. Furthermore, the phenomenon of pollution in the Ciujung River which is getting blackened in Serang Regency is caused by PT. Indah Kiat Pulp \& Paper made Wahidin Halim (Governor of Banten) impose sanctions and report violations of the Law as of July 10, 2019 to be tried in court [5].

Currently, the concept of sustainability is the most important concept to be implemented in company operations. Sustainability development is a development to meet the needs of the present generation without disturbing the ability of future generations to meet their needs [6]. Sustainability will shift the company's paradigm, no longer about profit, but the company's own going concern. Companies must focus on so that the operations carried out are beneficial to the community around the company (people), the environment around the company (planet) and finally the profit expected by the company (profit). This concept is known as the triple bottom line [7]. This can be done through the environmental performance of the company. The environmental performance carried out by a company will have a positive impact on the company itself in increasing the company's profits and value in the eyes of the community. The company's value is marked by a good image for the surrounding community so that the community can give legitimacy to support the company's operational activities.

Research on the environmental performance of companies is still relatively rare, especially in Indonesia. Existing research only measures environmental performance based on secondary data sourced from annual reports and company sustainability reports. But unfortunately, the research conducted was not in-depth, it only focuses on items that are disclosed in the annual report and company sustainability without showing how much the company's actual environmental performance has been carried out. Therefore, more in-depth research is needed with direct observation and interview approach related to environmental performance using the Global Reporting Initiative (GRI) version 4.0 standard proxy developed using 9 dimensions with 14 indicators.

\section{LITERATURE REVIEW}

Environmental performance is the company's performance to create a green environment [8]. Environmental performance is an important step for a company to achieve business success. Environmental performance is an outcome that can be measured through an environmental management system based on environmental policies, environmental targets and environmental targets [9]. In this study, the development of an environmental performance questionnaire uses a model developed by the Global Reporting Initiative (GRI 4.0) with 14 indicator items taken from 4 dimensions, namely: material input, non-product output, compliance aspects, and transportation aspects. The company has a long-term goal to increase company value by increasing the prosperity of its owners or shareholders [10]. Firm value is investors' perception of value, which is often related to the company's stock price. Firm value also describes the financial performance carried out by management in managing their finances [11].

The firm value in this study refers to the research of [12] using Tobin's Q. This ratio is considered to provide the best information, because in Tobin's $\mathrm{Q}$ includes all the elements of liabilities and equity of the company's shares, not only ordinary shares, and not only company equity that is included, but all company assets. By including all company assets, it means that the company is not only focused on one type of investor, namely investors in the form of shares, but also for creditors because the source of company operational financing is not only from equity but also from loans provided by creditors [13]. So, the greater Tobin's Q value indicates that the company has good growth prospects.

Based on the discussion that has been submitted, the hypotheses in this study are:

$\mathrm{H}_{1}$ : Environmental performance through the input material dimensions has an effect on firm value

$\mathrm{H}_{2}$ : Environmental performance through the non-product output dimension has an effect on firm value

$\mathrm{H}_{3}$ : Environmental performance through the dimensions of the compliance aspect has an effects on firm value

$\mathrm{H}_{4}$ : Environmental performance through the dimensions of the transportation aspect has an effect on firm value

$\mathrm{H}_{5}$ : Environmental performance through the dimensions of material input, non-product output, compliance aspects, and transportation aspects simultaneously affects firm value.

The research paradigm in Figure 1 below regulates the relationship of environmental performance that is carried out consistently to identify costs, especially environmental costs, to be controlled, in the end it can increase firm value. Companies need information on environmental costs to determine the environmental 
performance that will be carried out. This information is obtained by the company if the company applies environmental performance as an important factor in increasing company value.

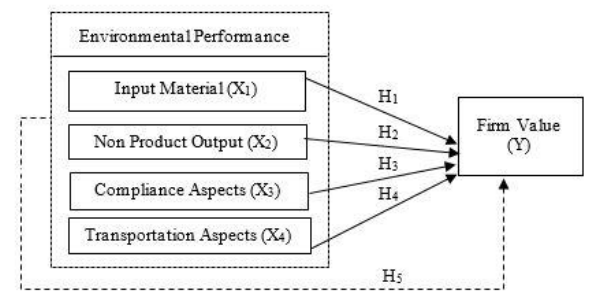

Figure 1. Research Paradigm

\section{RESEARCH METHOD}

The population in this study were all manufacturing companies located in Banten Province for the 2016 to 2018 period, totaling 1,695 companies. The sampling method was purposive sampling with the following criteria:

a. A manufacturing company domiciled in Banten Province, in the form of a Limited Liability Company and listing on the Indonesia Stock Exchange for the period 2016 to 2018 ;

b. The company participated in the Company Performance Rating Program in Environmental Management (PROPER) from KLHK for the period 2018;

c. A city or regency is represented by a maximum of five companies based on the highest PROPER ranking;

d. Complete available data.

The types of data used in this study are primary data obtained through questionnaires, and secondary data obtained through company financial reports. The data testing was carried out using SPSS (Statistical Package for Social Science) version 26.0 with the following types of tests [14]:

a. Validity test: correlates between scores of questions with the total score of constructs or variables.

b. Reliability test: performing the one shot method with a construct or variables is said to be reliable if it gives a Cronbach Alpha value> 0.60 .

c. Classic assumption test: normality, multicollinearity, and heteroscedasticity test.

d. Multiple linear regression test: perform regression with the model according to "Equation (1)".

FVit $=\alpha 0+\alpha 1$ MAIit $+\alpha 2$ NPOit $+\alpha 3$ KEPit $+\alpha 4$ TRAit + Ei (1)

e. Determination Coefficient Test $\left(\mathrm{R}^{2}\right)$ : The coefficient of determination $\left(\mathrm{R}^{2}\right)$ is used to measure the ability of the model to explain the variation in the dependent variables.

f. Simultaneous Test (Test-F): shows how far the independent variable as a whole explains the variation of the dependent variable.

g. Partial Test (t-test): shows how far the influence of one independent variable individually in explaining the variation of the dependent variable.

\section{RESULTS AND DISCUSSION}

Based on the sample selection method used, namely the purposive sampling method, the number of respondents who became the object of this study was 71 respondents consisting of employees at the top management, middle management and lower management levels in each manufacturing company in Serang Regency. A total of 71 selected respondents were employees representing 5 manufacturing companies that received PROPER ratings in Serang Regency, Banten. As described in Table 1 below:

Table 1. Data of Research Respondents

\begin{tabular}{|c|l|c|}
\hline No & \multicolumn{1}{|c|}{ Company Name } & Respondents \\
\hline 1 & ADMG & 15 \\
\hline 2 & JPFA & 15 \\
\hline 3 & MAIN & 15 \\
\hline 4 & CPIN & 15 \\
\hline 5 & GJTL & 11 \\
\hline \multicolumn{2}{|c|}{ TOTAL } & 71 \\
\hline
\end{tabular}

\subsection{Validity Test}

This validity test uses the help of SPSS version 26.0 for windows. The results of the validity test are shown in Table 2 below:

Table 2. Results of Validity Test

\begin{tabular}{|c|c|c|c|c|}
\hline Question & t-count & t-tabel & $N$ & Result \\
\hline 1 & 0,625 & 0,234 & 71 & Valid \\
\hline 2 & 0,624 & 0,234 & 71 & Valid \\
\hline 3 & 0,633 & 0,234 & 71 & Valid \\
\hline 4 & 0,620 & 0,234 & 71 & Valid \\
\hline 5 & 0,778 & 0,234 & 71 & Valid \\
\hline 6 & 0,790 & 0,234 & 71 & Valid \\
\hline 7 & 0,710 & 0,234 & 71 & Valid \\
\hline 8 & 0,757 & 0,234 & 71 & Valid \\
\hline 9 & 0,772 & 0,234 & 71 & Valid \\
\hline 10 & 0,795 & 0,234 & 71 & Valid \\
\hline 11 & 0,697 & 0,234 & 71 & Valid \\
\hline 12 & 0,747 & 0,234 & 71 & Valid \\
\hline
\end{tabular}




\begin{tabular}{|l|l|l|l|l|}
\hline 13 & 0,671 & 0,234 & 71 & Valid \\
\hline 14 & 0,718 & 0,234 & 71 & Valid \\
\hline
\end{tabular}

Based on the results of running the research instrument validity test in Table 2 above, it can be show that the values in the Corrected Item-Total Correlation ( $\mathrm{r}$ count) column are all greater than the r-table value, namely 0.234 which is obtained from the value equation $(\mathrm{df})=\mathrm{n}-2$, it is known that for the total sample (n) of 71, it is obtained $\mathrm{df}=71-2=69$. Based on the value in the $\mathrm{r}$ table for df 69 with a significance level for the two tailed test of $5 \%$ of 0.234 . Therefore, it can be concluded that all the data used are valid.

\subsection{Reliability Test}

This reliability test uses SPSS version 26.0 for Windows. The results of the calculations are shown in Table 3. the following:

Table 3. Reliability Statistics

\begin{tabular}{|c|c|}
\hline Cronbach's Alpha & N of Items \\
\hline .948 & 14 \\
\hline
\end{tabular}

The results of the reliability test that have been carried out in this study are Alpha Cronbach's value of 0.948. To find out this reliability test, we refer to the book Triton (2005) which classifies the scale into 5. Crobanch's Alpha value of 0.948 is included on a scale of 5, namely Cronbach's Alpha value of 0.81 to 1.00 , which means that this study is very reliable.

\subsection{Classic Assumption Test}

\subsubsection{Normality Test}

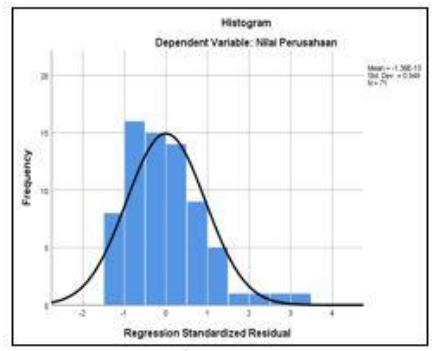

Figure 1. Data Normality Test Results

Based on the Figure 1 above, it is found that the dots spread around the diagonal line, and the spread follows the direction of the diagonal line. This regression model is feasible to be used to predict firm value based on the input of input material variables, non-product output, compliance aspects, and transportation aspects as a proxy for environmental performance. Thus, this regression model fulfils the normality assumption.
The results of the normality test using the KolmogrovSmirnov statistical test are by looking at the KolmogrovSmirnov value and the significance of the processed data. From Table 4 below, it can be seen that the magnitude of the Kolmogrov-Smirnov value (statistical test) is 0.089 and significant at 0.200 or $20.0 \%$, this means that the residual data is normally distributed because the significance is above 0.05 or $5 \%$.

Table 4. Data Normality Test Results

\begin{tabular}{|l|l|c|}
\hline & & $\begin{array}{c}\text { Unstandardized } \\
\text { Residual }\end{array}$ \\
\hline N & & 71 \\
\hline & Mean & .0000000 \\
\hline Most Extreme Differences & Std. Deviation & .57780318 \\
\hline & Absolute & .089 \\
\hline & Positive & .089 \\
\hline & Negative & -.062 \\
\hline Test Statistics & & .089 \\
\hline Asymp. Sig.(2-tailed) & & $.200^{c, d}$ \\
\hline
\end{tabular}

\subsubsection{Multicollinearity Test}

The tolerance test results show that there are no independent variables that have a tolerance value less than $0.10(10 \%)$. The results of the Variance Inflation Factor (VIF) calculation, show that there is no one independent variable that has a Variance Inflation Factor (VIF) value of more than 10 . Therefore, it can be concluded that there is no multicollinearity between variables in the regression model based on Table 5 below:

Table 5. Multicollinearity Test Results

\begin{tabular}{|c|l|c|c|}
\hline Model & & Tolerance & VIF \\
\hline 1 & (Constant) & & \\
\hline & MAI & .271 & 3.696 \\
\hline & NPO & .216 & 4.621 \\
\hline & KEP & .482 & 2.075 \\
\hline & TRA & .397 & 2.517 \\
\hline
\end{tabular}

\subsubsection{Heteroscedasticity Test}

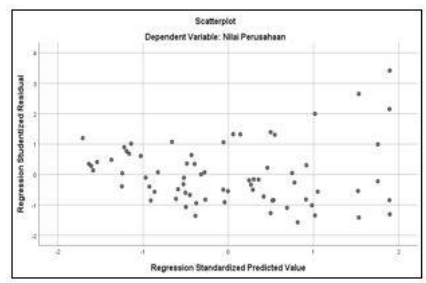

Figure 2. Heteroscedasticity Test Results 
Based on Figure 2 above, it can be seen that there is no clear pattern, and the dots spread above and below the 0 on the $\mathrm{Y}$-axis. Therefore, it can be concluded that there is no heteroscedasticity between the variables in the regression model.

Table 6. Coefficient of Determination

\begin{tabular}{|c|c|c|c|c|}
\hline Model & $R$ & R Square & $\begin{array}{c}\text { Adjusted R } \\
\text { Square }\end{array}$ & $\begin{array}{c}\text { Std. Error } \\
\text { of the } \\
\text { Estimate }\end{array}$ \\
\hline 1 & $.717^{\mathrm{a}}$ & .515 & .461 & .60906 \\
\hline
\end{tabular}

\subsection{Coefficient Of Determination}

Based on Table 6 above, we can see that the coefficient of determination which shows the adjusted $\mathrm{R}^{2}$ value is 0.461 . Because the adjusted $R^{2}$ value is below 0.5 , the ability of the independent variable to influence the dependent variable is limited. This also means that $46.1 \%$ of the variation in the level of firm value can be explained by environmental performance variables represented by input material variables, non-product output, compliance aspects, and transportation aspects. Meanwhile, $53.9 \%$ of the company's value level can be explained by other variables, such as good name (brand image) and company reputation.

\subsection{Multiple Regression Analysis}

Table 7. Results of Multiple Regression Analysis

\begin{tabular}{|l|l|c|c|c|}
\hline \multicolumn{2}{|l|}{} & $\begin{array}{c}\text { Unstandardized } \\
\text { Coefficients } \\
\text { Model }\end{array}$ & $t$ & Sig. \\
\hline 1 & (Constant) & 1.727 & 2.951 & .004 \\
\hline & Input Material & -2.187 & -3.949 & .000 \\
\hline & $\begin{array}{l}\text { Non Product } \\
\text { Output }\end{array}$ & .961 & 1.793 & .078 \\
\hline $\begin{array}{l}\text { Compliance } \\
\text { Aspects }\end{array}$ & .014 & .056 & .956 \\
\hline $\begin{array}{l}\text { Transportation } \\
\text { Aspects }\end{array}$ & -.182 & -.630 & .531 \\
\hline
\end{tabular}

Based on the results of regression testing in Table 7 above, an equation can be formed as follows:

$\mathrm{FV}=1,727-2,187 \mathrm{MAI}+0,961 \mathrm{NPO}+0,014 \mathrm{KEP}-$ $0,182 \mathrm{TRA}+\mathrm{e}$

\subsection{Simultaneous Parameter Significance Test}

Based on Table 8 below, it can be seen that the variables of input material (MAI), non-product output (NPO), compliance aspects (KEP), and transportation aspects (TRA) simultaneously have a significant effect on firm value. This is evidenced by the test results in Table 8 below, where the significance level of 0.000 is smaller at $\alpha=0.05(<0.05)$. Thus, environmental performance which consists of input material, nonproduct output, compliance aspects, and transportation aspects simultaneously affects the level of firm value.

Table 8. Results of Multiple Regression Analysis

\begin{tabular}{|l|c|c|c|c|c|c|}
\hline \multicolumn{2}{|c|}{ Model } & $\begin{array}{c}\text { Sum of } \\
\text { Squares }\end{array}$ & Df & $\begin{array}{c}\text { Mean } \\
\text { Square }\end{array}$ & F & Sig. \\
\hline 1 & Regression & 24.771 & 7 & 3.539 & 9.540 & $.000^{\mathrm{b}}$ \\
\hline Residual & 23.370 & 63 & .371 & & \\
\hline & Total & 48.141 & 70 & & & \\
\hline
\end{tabular}

\subsection{Significance Test of Individual Parameters}

Table 9. T-Test Results

\begin{tabular}{|c|l|c|c|c|}
\hline \multicolumn{2}{|c|}{ Model } & B & $t$ & Sig. \\
\hline 1 & (Constant) & 1.727 & 2.951 & .004 \\
\hline & Input Material & -2.187 & -3.949 & .000 \\
\hline & Non Product Output & .961 & 1.793 & .078 \\
\hline & Compliance Aspects & .014 & .056 & .956 \\
\hline & Transportation Aspects & -.182 & -.630 & .531 \\
\hline
\end{tabular}

\subsubsection{Analysis of The Effect of Input Material On Firm Value}

Based on the results of testing the input material variable (MAI) on the level of firm value (FV), it was found that the value of $\beta 1$ was -2.187 with a significant level of 0.000 , which was smaller at $\alpha=0.10$, this means that the material aspects of input had a significant negative effect on firm value. Although, the level of input material in the descriptive statistical analysis was not sufficient, the material aspects of input had a negative effect on firm value. The reason why environmental performance through the input material aspect has a negative effect on firm value is because based on the data obtained, it is found that although the score for input material from one of the manufacturing companies in Serang Regency is the highest, the company value obtained is lower.

\subsubsection{Analysis of The Effect of Non-Product Output On Firm Value}

The results showed that the $\beta 2$ value was 0.961 with a significance level of 0.078 , which was smaller at $\alpha=$ 0.10 , thus environmental performance through the nonproduct output (NPO) aspect had a significant positive 
effect on firm value (FV). The reason why environmental performance through the non-product output aspect has a positive effect on firm value is that based on the data obtained, it was found that the non-product output aspect of one of the manufacturing companies in Serang Regency which received the highest score was proven to have high firm value among other companies.

\subsubsection{Analysis of The Effect of Compliance Aspects on Firm Value}

Based on the partial test results of the compliance aspect variable (KEP) on firm value (FV), it can be seen that the $\beta 3$ value is 0.014 with a significance level of 0.956 which is greater at $\alpha=0.10$, thus the compliance aspect has a positive but insignificant effect on firm value, this is reinforced by the score of the level of company compliance in the descriptive statistical analysis is categorized as insufficient and not yet in the good category.

The reason that can explain this is based on the results of an analysis of one of the annual reports of manufacturing companies in Serang Regency. It is found that there is a very low value of compliance, especially regarding fines and monetary sanctions received due to environmental problems caused. So, that it can be concluded, the lower the role of the company in complying with aspects of compliance with environmental laws and regulations, the smaller the value of the company is received. This is because, at this time investors are starting to be smart in choosing a company as a place to invest and investors are more than happy and enthusiastic to invest in a company, one of which is to maintain the balance of nature and not to harm the surrounding community from the results of the production activities carried out by the Company.

\subsubsection{Analysis of The Effect of Transportation Aspects On Firm Value}

The results showed the value of $\beta 4$ was -0.182 with a significance level of 0.531 where the value was greater at $\alpha=0.10$, thus environmental performance through the transportation aspect (TRA) had a negative but insignificant effect on firm value $(\mathrm{FV})$. This is also supported by the score for the level of transportation aspects presented in the descriptive statistical analysis in the insufficient category and not yet in the good category. The reason that can explain this is that manufacturing companies in Serang Regency, Banten have not maximally carried out the process of recording and reporting related to the environmental impact of the activities of transporting products and other materials as well as company operational materials and work transportation. However, it was also found that one manufacturing company experienced an increase in company value even though the score for the transportation aspect was small.

\subsubsection{Analysis of The Effect Of Environmental Performance on Firm Value}

Table 8 describes the results of simultaneous environmental performance testing which includes input material variables (MAI), non-product output (NPO), compliance aspects (KEP), and transportation aspects (TRA) to firm value (FV). Based on Table 8, simultaneously the four variables representing environmental performance are proven to have an effect on firm value. This is evidenced from the test results in Table 8 above, where the significant value is 0.000 , which is smaller at $\alpha=0.10$. Thus, environmental performance which consists of input material, nonproduct output, compliance aspects, and transportation aspects simultaneously affects the firm value level with the result of a perfect significance level (0.000).

Overall, it can be concluded that the environmental performance that has been carried out by manufacturing companies in Serang Regency, Banten is quite good and the benefits are sufficient both from the internal and external aspects of the company. However, based on the results of the survey and interview, it was found that several points should be addressed and improved in the environmental performance of the manufacturing company in Serang Regency, Banten.

\section{CONCLUSIONS}

The input material aspect has a significant negative effect on firm value. The non-product output aspect has a significant positive effect on firm value. Compliance and transportation aspects have a positive and negative influence but are not significant to company value. Furthermore, based on the results of simultaneous testing (F test), it can be concluded that environmental performance through input material aspects, non-product output aspects, compliance aspects, and transportation aspects simultaneously have a significant effect on firm value.

This research implies that the company is expected to further improve environmental performance, especially in the aspects of compliance and transportation. In the aspect of compliance, companies are required to comply more fully with the fines and non-monetary sanctions that should be accepted under the Company Law and Environmental Regulations and are required to report them in the company's annual report. The next aspect is the transportation aspect, companies are required to pay attention to the unit (car) as a means of transporting materials, products and labor with an environmentally friendly unit (minimum carbon emission produced). Even though these two aspects are compliance, they are quite important to pay attention to and practice can be 
improved. This is because environmental performance must be consistent with the increase in the score of each main function so that the implementation practice can run consistently, thoroughly and optimally in order to increase the value of a company.

\section{REFERENCES}

[1] Daily. I, Kawasan Industri Banten Jadi Proyek Percontohan di Luar Jawa, Berita Industri Kementerian Perindustrian RI, 2015, https://kemenperin.go.id/artikel/14666/KawasanIndustri-Banten\%20-Jadi-Proyek-Percontohan-diLuar-Jawa.

[2] Ansori. M, Menperin Incar Investasi Sektor Kimia Hingga Baja. 2019, https://www.neraca.co.id/article/117667/menperinincar-investasi-sektor-kimia-hingga-baja.

[3] Banten. F, Pemerintah Didesak Atasi Persoalan Kerusakan Lingkungan di Banten. Fakta Banten, 2017 http://faktabanten.co.id/pemerintah-didesakatasi-persoalan-kerusakan-lingkungan-di-banten/.

[4] Irfan. A, 418 industri di Tangerang disanksi terkait pencemaran limbah. Antara Banten, 2019, https://banten.antaranews.com/berita/37601/418industri-di-tangerang-disanksi-terkait-pencemaranlimbah.

[5] Mahyadi, Sungai Ciujung Tercemar, Gubernur Banten Minta Industri Diseret ke Pengadilan, Banten Hits., 2019, https://bantenhits.com/2019/07/11/sungai-ciujungtercemar-gubernur-banten-minta-industri-diseretke-pengadilan/.

[6] NCSR, Sustainability Reporting Guidelines (versi GRI-G4 Bahasa Indonesia), 2019, http://www.globalreporting.org.

[7] Elkington. J, Cannibals with Forks: The Triple Bottom Line of 21st Century Business, 1997, Oxford: Capstone Publishing Ltd.

[8] Suratno. I. B, Pengaruh Environmental Performance terhadap Environmental Disclosure dan Economic Performance (Studi Empris pada Perusahaan Manufaktur yang terdaftar di Bursa Efek Jakarta periode 2001-2004), 2007, Simposium Nasional Akuntansi 9.

[9] Purwanto, Pengukuran Kinerja Lingkungan, 2004, http://andietri.tripod.com/.

[10] Wahidahwati, Kepemilikan Manajerial dan Kepemilikan Intitusional pada Kebijakan Hutang Perusahaan; Sebuah Perspektif Theory Agency, 2002, Simposium Nasional Akuntansi (SNA) IV.
[11] Suroto. S, Pengaruh Keputusan Investasi, Keputusan Pendanaan, dan Kebijakan Dividen terhadap Nilai Perusahaan, 2015, ISSN: 2302-2752, Vol. 4 (3).

[12] White. et al., The Analysis and Use of Financial Management, 2002, John Wiley and Sons.

[13] Sukamulja. S, Good Corporate Governance di Sektor Keuangan: Dampak Good Corporate Governance Terhadap Kinerja Keuangan, 2004, Simposium Nasional Akuntansi VII.

[14]Ghozali. I, Aplikasi Analisis Multivariate dengan Program SPSS, 2006, Semarang: Badan Penerbit Universitas Diponegoro. 